\title{
Methyl 2,5-dihydroxycinnamate
}

National Cancer Institute

\section{Source}

National Cancer Institute. Methyl 2,5-dihydroxycinnamate. NCI Thesaurus. Code C1305.

A cell-permeable analog of erbstatin, a compound isolated from Streptomyces that inhibits the autophosphorylation of epidermal growth factor receptor. Erbstatin analogue competitively inhibits epidermal growth factor receptor-associated tyrosine kinase, inhibiting the activation of $\mathrm{v}$-abl tyrosine kinase. In addition, this agent has induced apoptosis in mouse thymocytes and inhibits the G2/M phase of the cell cycle. $(\mathrm{NCl})$ 